\title{
Research on College Students' Autonomous English Learning
}

\author{
Yongmei $\mathrm{Cao}^{1, *}$
}

\author{
${ }^{1}$ Xi'an Fanyi University, Xi'an, Shaanxi 710105, China \\ *Corresponding author. Email: 466071360@qq.com
}

\begin{abstract}
As a learning method, autonomous learning is different from the traditional one-way teaching and learning mode, in which students are treated as the main body of learning, they set learning goals, complete learning tasks, and acquire knowledge all by themselves, but under the guidance of teachers. At present, it is a trend that many English teachers in colleges and universities choose to use English learning websites or apps to assist their daily teaching, which shows a great development in higher education, especially in the aspect of improving students' autonomous learning. Convenient as it is, it also brings a lot of problems, of which "no motivation" has already become into the "bottleneck" of autonomous English learning, and at the same time, learning motivation seems to be a very important factor in promoting autonomous English learning. This article, based on the detailed investigation and interview, mainly analyzes the status quo and problems of college students' English learning and then proposes some solutions to the existing problems, therefore to enhance both teaching and learning efficiencies by fostering college students' learner autonomy.
\end{abstract}

Keywords: Autonomous learning, College English, Methods, Motivation.

\section{INTRODUCTION}

With the rapid development of new technologies, new media represented by the Internet, mobile phones, electronic book, We Chat, etc., have deeply affected People's way of life. Students in colleges and universities are of no exception. They have great abilities to accept new things, and their love and pursuit of new media are unprecedentedly high. New media impacts the entire campus culture, penetrates into the study and life of college students, and profoundly affects their ideas, learning behaviors and daily interactions. At the same time, great changes have taken place in the way school educates students and the way students learn new things. Now, with the continuous education reform and development in our country, cultivating students' independent learning ability has become an important task for the teachers, which remains a very tough question. Because for a long time in the past, university

*Fund: The Project on Scientific Research of 2021 Xi'an Fanyi University, Research on the Current Situation and Guidance Strategies of College Students' Autonomous English Learning in the New Media Era, Project No.: 21B49 students in China have received an exam-oriented education, which is mainly teacher-centred, lacking students' involvements and innovation[1]. However, autonomous learning ability is the foundation of innovation. If students are to have better innovation ability, then we have to adapt to the continuous changes in society, and train students to be self-disciplined and to learn autonomously.

\section{THE STATUS QUO OF COLLEGE ENGLISH AUTONOMOUS LEARNING}

Today, with the rapid development of new media, mobile interoperability and interconnection are profoundly affecting college students' concepts and behaviour patterns of understanding and perceiving the world. The abundance of learning resources, the convenient means of acquiring knowledge, and the rapid spread of knowledge have greatly improved college students' horizons, innovation and research abilities as well. On the one hand, college students can learn English everywhere and at any time, which lays a good 
foundation for those who can manage their time well and learn by themselves. On the other hand, for students with weak self-control, the introduction and widespread prevalence of new media has undoubtedly increased the misleading and temptation. Those students always indulge themselves in all kinds of on-line activities, which include games, chatting, shopping, browsing, etc., and they simply cannot get enough time to study, which in turn causes their poor English academic performances and results. Sometimes things are much worse than that.

There are many reasons for this phenomenon. One is that for some students, they have difficulty in learning English. Some students try hard at first, but when there is no improvement, they give up and then pay attention to somewhere else, such as games on mobile phone, chatting, or shopping online, etc. Second, the traditional teaching method may have already lost its flavor and cannot attract students' attention any more. Another important reason accounting for this is college students' weak autonomous learning abilities. Because for many years, Chinese students are studied in an examoriented educational setting, where there are always teachers to supervise students, guide students to learn and to do homework. Once there is no teacher's prompt supervision, no teacher tells them what to learn and how to learn, they are at a loss, and lose the direction and motivation to learn. Therefore, students with weak autonomous learning ability will lag far behind those students with strong independent learning ability and gradually lose interest in English learning, which is sad enough and needs to be solved urgently[2].

\section{METHODS TO CULTIVATE STUDENTS' AUTONOMOUS LEARNING ABILITY}

In response to the above reasons, we need to find feasible ways to enhance college students' selfdiscipline and autonomous learning ability.

First, the teaching methods of college English should keep pace with the changing environment. For a very long time, we applied the traditional teaching method for English, which is teachercentred, exam-oriented, and lack of creativity. But in such a rapidly developed digital age, students have already been equipped with all kinds of tools to search for useful information, and there is no need to leave a great amount of time for those basic knowledge[3]. Student should be encouraged to search for the basic information related to the issue in question and also be encouraged to present those information by themselves. Only by doing that, can they change their passive learning mode to kind of active learning mode in which students are the explorers and the centre of learning instead of teachers. On the other hand, teachers should spare no effort to develop students' automatic learning ability, and deal with problems that students can't solve or still have difficulty in understanding them during class, instead of those easy ones that can be done by students themselves after class.

Second, make full use of online resources. Now information technology is profoundly changing people's lives, especially in the field of education, and internet-assisted education has become popular for all education practitioners. At the same time, the products of the combination of the Internet and education are also increasing, such as online classes, micro-courses, digital learning systems, and various English learning websites, etc. Through these channels, students can adjust their own learning pace and learning contents accordingly. On the one hand, for those who cannot follow teachers' teaching during the class, they can find the related teaching videos or other forms of explanations online and to catch up what they failed to understand in the class. On the other hand, for those who have a larger capacity in learning and want to dig dipper about certain topics, they can still satisfy their curiosity from online resources[4]. However, things are sometimes difficult to balance. During and after the breakout of COVID-19, there is a phenomenon that most of the courses are taught in a way that combines ordinary teaching and online teaching. Under such circumstances, students are asked to have both forms of teaching at the same time, and most probably, to finish both forms of teaching before the end of the semester. Therefore, in order to finish on time, students are forced to play teaching videos during other classes, even without watching them, just to put the videos to the end... What a pity! A lot of teachers spent their day and night preparing these online materials, and surely they don't want to see this! Then what's the problem? In our school, averagely, each freshman has 13 classes each weak, each being 1.5 hours, which means they have 3 classes almost every day, besides, they have homework for each course, and then online materials for each course... Now we can imagine how busy they are, and then their in-class non-related video-playing seems to be justified. On the contrary, the rate to pass TEM 4 and TEM 8 doesn't seem to improve in such an omnimedia era in which students have an easy access to all kinds 
of learning materials. According to the students in our school, most of them showed unwillingness to watch the videos and course-related materials online while there are ordinary classes offline provided. Then what's going wrong here? Is that the proportion of online and offline material ill distributed? Or Students' motivations for self learning haven't been aroused yet?

In order to solve this problem, there must be a reasonable proportion to combine the on-line and off-line courses. Teachers should design teaching method first, and then arrange teaching content and on-line resources properly and then hopefully to enhance teaching efficiency[5]. To achieve this, we should consider the following procedures:

- Before class, teachers should release the related on-line resources in advance, assigning previewing task. For college English, teachers are suggested to raise some content-based questions for the students to get an outlook of the text and to finish the related the questions based on their on-line previewing work. It's better to encourage students to bring their own questions and understandings of certain tasks to class and have a discussion with teachers and students alike.

- During class, teachers should check on the on-line previewing work and elaborate on those difficult points because students have already had a general understanding of the text after on-line previewing. It's good to set up activities like debate, discussion, team presentation to encourage students to express their own idea and cultivate students' critical thinking during this period.

- After class, teachers should help students with unsolved questions related to the text being discussed. Besides, after-learning test can be given on this occasion, from which students' learning results can be examined and they can find their weaknesses and then to catch up on line by themselves.

Anyway, this kind of on-line courses should be an optional complement to the off-line in-class teaching, instead of being compulsory, which will cause burden or learning-weariness for some students.

Third, we should stimulate students' motivation for English learning[6]. Equipped with various learning facilities, some college students still have difficulty in English learning. The key reason is that their inner motivation is not aroused. They don't have a clear goal for English learning, and they don't know how to learn well. To solve this problem, teachers should first of all come closer to students and be their friends. And then we can get to know the students' inner heart, their likes, dislikes, strengths, and weaknesses. Only this way, can we encourage students and foster their interests in English, since interest is the best teacher. Then we should let students know the importance of learning English, which will help them set up a proper goal for learning this course. Finally, try to figure out ways suitable for certain students. Because students are different in their comprehension for new knowledge, we should allow those slow-learners enough time to digest new things. Practice makes perfect, as long as students are willing to learn English, they will do it in the end.

\section{CONCLUSION}

English learning is a long and difficult process which requires strong learning motivation to sustain. If we only focuses on the teaching and training of language knowledge and skills, and do not pay attention to cultivating students' learning motivation, it will be hard to mobilize and maintain students' enthusiasm and initiative for English learning[7]. Besides, teaching should be kind of "teaching people how to fish than to just give them fish." As teachers, we should teach students the way to learn, develop their learning habits and cultivate their learning abilities. At present, the internet-assisted English teaching has already become a trend for college English teachers to innovate their teaching methods, and also for students who want to enrich their knowledge themselves. More students benefit from the method and continuously improve their independent learning ability. On the other hand, students are flooded with all kinds of information and new media, it's important to tell them the correct way to differentiate the right and the wrong, and spare no effort to cultivate students' autonomous learning abilities, which will do good to students for the rest of their lives[8]. Next, teachers should combine online and ordinary teaching wisely and properly to maximize their teaching effect, instead of only confined to form. Most importantly, teachers should come to students' heart, be friends with them, and therefore enhance students' confidence in learning. 


\section{AUTHORS' CONTRIBUTIONS}

This paper is independently completed by Yongmei Cao.

\section{REFERENCES}

[1] Li Jing. Research on the Improvement of College Students' Autonomous Learning Ability in the New Media Environment [D]. Shandong University, 2017.

[2] Chen Jie. Research on Student Engagement in Online Autonomous Learning [M]. Beijing: Beijing Jiaotong University Press, 2015.

[3] Liu Min. Smart phone-based autonomous English learning for college students under the concept of micro-learning [J]. Software Guide (Educational Technology), 2015, 14(03): 3234.

[4] Wang Ning, Li Ying, Wang Xing. An Empirical Study on Interactive Teaching Effects of College English Autonomous Learning Websites [J]. High Education Journal, 2015(09): 16-17.

[5] Xiang Huang. Exploration of the Construction of Maritime English Autonomous Learning Platform [J]. International Journal of Social Science and Education Research, Volume 4, Issue 5. 2021.

[6] Xiao Longyuan. Motivation of Students' Autonomous Learning in English MOOC Teaching Based on Big Data Analysis. Journal of Physics: Conference Series [J], Volume 1881, Issue 2. 2021.

[7] Xie Lijun. Research on the Autonomous Learning Model of College English Based on English Special Learning Website [J]. Campus English [J], 2020(31): 51-52

[8] Zhang Rui,Zhang Jingbo. A Review of Domestic College English Autonomous Learning Research [J]. Talent, 2019(09):1820. 